DOI 10.1515/linpo-2017-0009

\title{
The coordinators $i$ and $z$ in Polish: A cognitive-typological approach (Part 2)
}

\author{
Alexander Andrason \\ Department of African Languages, University of Stellenbosch \\ andrason@sun.ac.za
}

\begin{abstract}
Alexander Andrason. The coordinators i and $\mathrm{z}$ in Polish: A cognitive-typological approach (Part 2). The Poznan Society for the Advancement of the Arts and Sciences, PL ISSN 0079-4740, pp. 7-22

Developed within the frame of cognitive and typological linguistics, the present study examines the taxonomical status of the lexemes $i$ and $z$ in Polish. To achieve this aim, the author analyzes the compliance of the two forms with the prototype of coordinate-hood and the structure of their maps of polyfunctionality. The evidence demonstrates that $i$ is a canonical instantiation of the category of coordinate-hood while $z$ is less canonical. Additionally, the two lexemes yield different maps of polyfunctionality (with distinct prototypicality nuclei), which reflects their distinct diachronic and conceptual origin. The map of $i$ radiates from the value of 'also' while the map of $z$ radiates from a comitative sense.

This article - the last in a series of two - completes the presentation of the empirical evidence and interprets it within the adopted framework. The degrees of canonicity of $i$ and $z$ are determined and the semantic-functional maps of the two lexemes are compared.
\end{abstract}

Keywords: Polish, coordination, cognitive linguistics, typology, radial categories, maps

\section{Introduction - Where we left off}

The present study analyzes the taxonomical status of two lexemes that, in Polish, may be used in a broadly understood coordinating function, namely $i$ and $z$ (Buttler et al. 1971; Kallas 1993; Haspelmath 2004; Bhat 2004; Willim 2012; Patejuk \& Przepiórkowski 2012; Prażmowska 2013; Przepiórkowski \& Patejuk 2014). ${ }^{1}$ By using the ideas of prototypes, radial networks, and semantic maps (Janda 2015; Hamawand 2016), common in

${ }^{1}$ In this study coordinating constructions (and thus terms such as coordinator, coordinand, coordination, coordinate-hood) only refer to conjunctive coordinating constructions, i.e. the so-called 'and'-type (Haspelmath 2004: 5). As explained in the previous article, there are other types of coordination, such as disjunctive coordination (the 'or'-type), adversative coordination (the 'but'-type) and causal coordination (the 'for'-type; Haspelmath 2004: 5-6). In coordinating constructions such as John and Mary, and is referred to as a coordinator while the elements linked by it are referred to as coordinands. 
cognitive linguistics and linguistic typology, I determine the degree of canonicity of $i$ and $z$ as conjunctive coordinators, and compare their respective ranges of functions and senses, including those that extend beyond coordination. The former objective consists of testing the two lexemes for their compliance with the features essential to the prototype of coordinators (Yuasa \& Sadock 2002; Haspelmath 2004). The later objective involves a comparison of the maps of the polyfunctionality of $i$ and $z$, and the determination of their overlap and dissimilarity.

The previous paper - the first in a series of two - familiarized the reader with the theoretical framework underlying the study and presented the empirical evidence related to the lexeme $i$. To be exact, $i$ has been tested for the presence of features that are associated with the crosslinguistic prototype of conjunctive coordinators, and its range of polysemy and polyfunctionality was described.

In the present article, I will offer a comparable analysis and description of the lexeme $z$. On the one hand, I will study the performance of $z$ on the tests of coordinate-hood and, on the other hand, I will describe the range of its polysemy and polyfunctionality. The results of the empirical study of $i$ and $z$ will enable me to determine the respective degrees of canonicity of the two lexemes when used as conjunctive coordinators, and estimate the overlap or dissimilarity of their semantic-functional radial networks.

To achieve this, the paper will be organized in the following manner. In section 2, the empirical evidence showing the phonetic, morpho-syntactic and discourse-pragmatic properties of the element $z$ will be introduced. In section 3, the evidence related to $i$ and $z$ will be analyzed within the approach adopted, and the contribution of this research to the cognitive-typological model of coordinate-hood will be discussed. Lastly, in section 4 , the main conclusions of the study will be drawn and lines of future research will be designed.

\section{Evidence - Coordinator $z$}

The lexeme $z$ may coordinate grammatical elements in Polish. In such cases, $z$ expresses the idea equivalent to the logical operators of conjunction $\wedge$ and intersection $\cap$ (cf. $\mathrm{F}$ (eature) 1 in the list of the 17 features associated with the prototype of conjunctive coordinators crosslinguistically; Andrason 2017). In example (1), if $z$ is employed instead of $i$, the information conveyed by the proposition is identical in terms of truth conditions. It indicates that both the woman and the man are murderers. This reading is especially common if the verb appears in the plural, that is, if the coordinands impose the plural agreement of the verb (on agreement see further below):

$$
\begin{aligned}
& \text { Kobieta z mężczyzną zabili dziecko } \\
& \text { woman with }{ }^{2} \text { man killed child } \\
& \text { 'The woman and man killed the child' }
\end{aligned}
$$

\footnotetext{
${ }^{2}$ In all the examples, the lexeme $z$ will be glossed as 'with' irrespective of its function and meaning.
} 
As far as symmetry is concerned (cf. F 2-6), the following can be noted. In coordinating uses, elements linked by $z$ may be equally salient, exerting a comparable control over the activity (cf. F 2). In example (1), introduced above, the man and the woman are equally guilty of the act of killing.

In a similar vein, the two coordinands may exhibit an identical status of topicality (cf. F 3), as demonstrated by their use in a left-dislocation construction (2a) and an introductory expression in narrative $(2 b)$.

(2) a. Co do kobiety z mężczyzną

as for woman with man

'As for the woman and man,

$\begin{array}{llll}\text { to } & \text { zabili } & \text { to } & \text { dziecko } \\ \text { PART } & \text { killed 3PL } & \text { that }\end{array}$

PART killed.3PL that child

they killed that child'

b. Żyli sobie mąż $\quad \mathrm{z} \quad$ żoną

lived REFL husband with wife

'Once upon a time there was a husband and wife'

However, if plural agreement is absent and the second coordinand is separated from the first one and placed in the adjunct position, the saliency and topicality of the coordinands are not equal. In sentences such as Kobieta zabiła dziecko z mężczyzna and Co do kobiety, to zabiła dziecko z mężczyna (which are variants of 1 and 2a), the coordinand kobieta receives greater saliency and is topicalized. The other coordinand mężcyzna is less salient and fails to constitute the topic of the sentence.

In certain cases, the order of the elements linked by $z$ can be reversed without any considerable influence on the truth condition of the entire proposition (F 4):

(3) a. Olek z Tomkiem poszli na spacer

Olek with Tomek went.3PL on walk

'Olek and Tomek went for a walk'

b. Tomek z Olkiem poszli na spacer

Tomek with Olek went.3PL on walk

'Tomek and Olek went for a walk'

In other instances, however, the word order of the proposition cannot be reversed, unless the form of the verb is changed. For example, the sentence in (4a) cannot be reversed if the form of the verb remains in the plural. In contrast, a similar sentence with $i$ would be grammatical even if the word order of the coordinands was changed and the verb was used in the plural (Mój przyjaciel $i$ ja poszliśmy do kina or Ja i mój przyjaciel poszliśmy do kina).

(4) a. Ja z moim przyjacielem poszliśmy do kina

I with my friend went.1PL do cinema

'I and my friend went to the cinema'

b. Mój przyjaciel ze mną *poszliśmy / poszedł do kina

my friend with me went.1PL went.3SG do cinema

'My friend and I (*we / he) went to the cinema' 
The nominal, adjectival or pronominal coordinands - the only types found in $z$ coordinating constructions - are never used in the same grammatical case (cf. F 5). To be exact, while the first coordinand may appear in any case, the latter coordinand is invariably inflected in the instrumental case (5a). If the first noun is used in the instrumental case, the second noun in the instrumental case will not be interpreted as coordinated to it. It will be read possessively (5b), comitatively, or as coordinated to the subject of the clause (5c; see the next paragraph).

\section{(5) a. Widziłem Tomka z dziewczyną \\ saw.1SG Tomek.ACC with girl.INSTR \\ 'I saw Tomek and (his) girlfriend'}

$\begin{array}{llll}\text { b. Zabił go kijem } & \text { z } & \text { gwoździem } \\ \text { killed.3SG him stick.INSTR with } & \text { nail } \\ \text { 'He killed him with a stick with a nail' } & \\ \text { c. Zabił go siekierą } & \text { z przyjacielem } \\ \text { killed.3SG him axe.INSTR with friend } \\ \text { 'He and his friend killed him with an axe' }\end{array}$

In its coordinating use, the lexeme $z$ connects elements that usually belong to the same lexical class and syntactic category (cf. F 6). Typically, the lexical class is a noun or pronoun (6a-c). Adjectives can also be used although only if they are substantivized or employed as epithets qualifying nouns. Other lexical classes (e.g. adverbs, prepositional phrases, adjectives (except for instances specified previously)) are never connected by $z$. It is also impossible to use $z$ to coordinate verbs, clauses or sentences. Coordinands typically function as subjects (6a), direct objects (6b) or indirect objects (6c). Objects that are introduced by prepositions are less frequent. In such cases, the phrase $[z+\mathrm{NP}]$ is usually interpreted possessively (Rozmawiatem o [samochodzie z przyczepa] 'I talked about the car with a trailer (that has a trailer)') or as comitative (Rozmawiatem o samochodzie $z$ matka 'I talked to my mother about the car'). The lexeme $z$ is never used in a coordinating function if it is linked to a noun introduced by the preposition $z$ (*Spotkałem się z [matka z córka]).

(6) a. Chłopiec z dziewczynką tam stoją boy with girl there stand

'There stands a boy and a girl'
b. Spotkałem
Olka
Tomkiem jak
grali
w piłkę
met.1SG
Olek with Tomek as played
in soccer
'I met Olek and Tomek as they were playing soccer'
c. Dałem to matce $\mathrm{z}$ córką gave.1SG this mather.DAT with daughter.INSTR
'I gave it to the mother and daughter'

As $z$ does not link clauses, the criterion of intonational phrasing or intonation break cannot be tested (cf. F 7).

The coordinands linked by means of $z$ usually imply both local and temporal simultaneity (cf. F 8). This reading is especially patent if no further specification is provided, 
being de facto a default interpretation of the $z$ construction (7a). However, it is also possible to add expressions that specify that the location and time of the two activities are different $(7 b)$.

(7) a. Ja z Anną widziałyśmy ten film
I with Anna saw.1PL.FM this film
'I and Anna saw this movie [together]'
b. Ja $\mathrm{z}$ Anną już to widziałyśmy
I with Anna already this saw.1PL.FM
I and Anna have already seen this'
Ja dawno temu w Warszawie, ona niedawno W Krakowie
I long.time ago in Warsaw she not long.time in Cracow
'I - long time ago in Warsaw, she - recently in Cracow'

As the second coordinand obligatory appears in the instrumental case, a choice between emphatic and dependent pronouns is not available (cf. F 9). The first coordinand tolerates both pronominal forms, depending on syntax and discourse pragmatic properties, namely, the dependent form (8a) and the emphatic form (8b):

(8) a. Widziałem go z żoną
sam.1SG him with wife
'I saw him with (his) wife'
b. Jego z żoną widziałem
him with wife saw.1SG
'I saw him with (his) wife'

In its coordinating uses, the lexeme $z$ allows both for verbal forms that exhibit plural agreement and for those that fail to do so, appearing in the singular form (cf. F 10). If the two NPs coordinated by $z$ precede the verb and are employed in the subject position/ function, both the plural and singular form of the verb may be used (9a). The meaning of examples where the verb is inflected in the singular is slightly less symmetrical than the meaning of sentences in which the verb is employed in the plural. That is, the first item (the one in the nominative) is given prominence while the latter seems to carry a more adjunctive (e.g. comitative) value. This can be observed in the following phenomenon: the phrase $[z+\mathrm{NP}]$ can always be placed after the verb, in the adjunct position. In such instances, the plural agreement is ungrammatical (9b). This inequality may also be perceived as far as the gender agreement is concerned. If two abstract inanimate nouns are connected by means of $z$, the verb may be used in the plural or the singular. If the singular form is used, its gender must agree with the first coordinand but not the latter one (9c). The latter coordinand can be placed in the postverbal, adjunct position. In such cases, the verb can only be inflected in the singular obligatorily agreeing with the first coordinand in gender $(9 \mathrm{~d})$.
(9) a. Tomek z Olkiem poszli /poszedł do szkoły Tomek with Olek went.3PL went.3SG to school 'Tomek and Olek went to school'


b. Tomek *poszli /poszedł do szkoły z Olkiem

Tomek went.3PL went.3SG to school with Olek

'Tomek went to school with Olek'

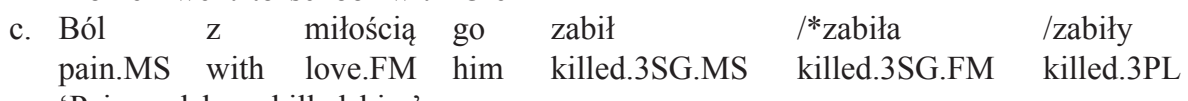
'Pain and love killed him'

d. Ból go zabił /*zabiła $/ *$ zabiły $\quad \mathrm{z}$ miłością pain.MS him killed.3SG.MS killed.3SG.FM killed.3PL with love.FM 'Pain and love killed him'

If the coordinands follow the verb, both singular and plural verbal forms may be used (10a). In such cases, both types of constructions (i.e. with the verb inflected in singular and plural) seem to imply similar symmetry and express the equal relevance of the two coordinands. If the coordinands are of a distinct gender, the gender of the verb must agree with the noun that is employed in the nominative case and not with the gender of the coordinand headed by $z$ (10b). This may also suggest a lesser degree of symmetry.
a. Przyszli /przyszedł Tomek z Olkiem came.3PL /came.3SG Tomek with Olek
'Tomek and Olek came'
b. Przyszed $¥$ Tomek z Zosią came.3SG.MS Tomek.MS with Zosia.FM
'Tomek and Zosia came'

As already mentioned, only noun and pronoun phrases can be linked by means of $z$ in its coordinating function. The coordination of adjective phrases (if not substantivized), adverb phrases, verb phrases and clauses is ungrammatical (cf. F 11).

Individual non-clausal $z$ phrases (i.e. $z+$ NP) can be extracted (11a). The first coordinand can also be extracted (11b). All such extracted elements can also be focused. Other extractions are ungrammatical (e.g. 11c) and the coordinator $z$ cannot be left behind (11d; cf. F 12)
a. $\left[\begin{array}{lll}Z & \text { Tomkiem }\end{array}\right]_{i} \quad$ widziałem Olka
with Tomek.INSTR saw.1SG Olek.ACC $^{-1}$
'I saw Olek and Tomek'
b. Olka widziałem $_{-i} \mathrm{z}$ Tomkiem
Olek.ACC saw.1SG with Tomek.INSTR
'I saw Olek and Tomek'
c. *[Olka $\quad \mathrm{z}]_{\mathrm{i}} \quad$ widziałem $-\mathrm{i}$ Tomkiem
Olek.ACC with saw.1SG ${ }^{-1}$ Tomek.INSTR
d. ${ }^{*}$ Tomkiem $_{\mathrm{i}} \quad$ widziałem Olka $\mathrm{z}$
Tomek.INSTR saw.1SG Olek.ACC with

Given that the lexeme $z$ does not link clauses, the test of backward anaphora cannot be applied (cf. F 13). It should however be noted that in contrast to the coordinator $i$, the co-indexation of the pronoun found in the second coordinand with the referent used 
in the first coordinand $\left(\mathrm{NP}_{\mathrm{i}} z \mathrm{PP}_{\mathrm{i}}\right.$ ) requires the use of reflexive possessive pronouns (see Haspelmath 2004: 36):

(12) Tomek $_{\mathrm{i}}$ ze swoim $_{\mathrm{i}} \quad / *$ jego synem przyszli

Tomek with his.REFL his.POSS son came.3PL

'Tomek and his (own) son came'

Although multiple conjuncts and multiple NPs are possible, this usage is extremely infrequent (cf. F 14):

$\begin{array}{llllllll}\text { Przyszli } & \text { Tomek } & \text { z } & \text { Olkiem, } & \text { z } & \text { Markiem, } & \text { z } & \text { Jankiem } \\ \text { came.3.PL } & \text { Tomek } & \text { with } & \text { Olek } & \text { with } & \text { Marek } & \text { with } & \text { Janek }\end{array}$

'Tomek and Olek, and Marek, and Janek came'

The coordinator $z$ can never be omitted even in multiple conjunct structures (cf. F 15):

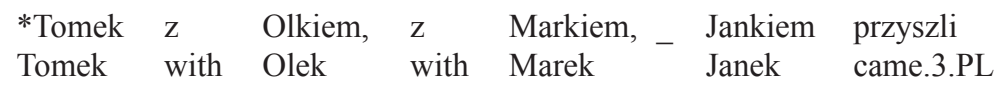

Intended meaning: 'Tomek and Olek, and Marek, and Janek came'

Coordinating constructions with $z$ cannot be used bi-syndetically (cf. F 16):

$\begin{array}{llllll}* \mathrm{Z} & \text { Tomkiem } & \mathrm{z} & \text { Olkiem } & \text { przyszli } & \text { / przyszed } \\ \text { with } & \text { Tomek } & \text { with } & \text { Olek } & \text { came.3SG } & \text { came.3PL }\end{array}$

Intended meaning: 'Tomek and Olek came'

The coordinating construction with $z$ can both precede the verb (16a), as is also typical of $i$, and follow it (16b-c), as is typical of adjuncts introduced by prepositions (cf. F 17):
a. Chłopak z dziewczyną spacerują /spaceruje boy with girl walk.3.PL walk.3SG
'A boy and a girl are walking'
b. Spacerują /spaceruje chłopak $\mathrm{z}$ dziewczyną walk.3.PL walk.3SG boy with girl
'A boy and a girl are walking'
c. Chłopak *spacerują /spaceruje z dziewczyną boy walk.3.PL walk.3SG with girl
'A boy is walking with a girl'

The $z$ construction has a clear prepositional structure [A] [co B] and the lexeme $z$ is defined in grammars as a preposition. $Z$ governs nouns, pronouns and adjectives (if they are substantivized or if they qualify nouns), regularly requiring an instrumental case marking. The instrumental case is compulsory irrespective of the position and function of the coordinator $z$ in the sentence, i.e. even if the entire coordinating construction [A z B] acts as the subject. As mentioned above, the coordinating element $z$ is only used with declension classes, thus being sensitive for the lexical class of coordinands. It is 
also relatively sensitive for the syntactic category of the coordinand as it is more commonly found when accompanying subjects and objects than accompanying prepositional complements. It is virtually never found in the coordinating function with adjuncts that appear in the instrumental case and/or that are preceded by a comitative or possessive type of $z$. As $z$ cannot link clauses, its relation to the sameness/distinctiveness of the subjects or the meaning of sequentiality cannot be assessed.

Apart from its use as a coordinator, $z$ can be employed in a variety of other functions. It is commonly used in the comitative function 'together with, in the company of' equivalent to razem $z$ and wespót $z$ (17a-b). This value can further be extended to inanimate nouns, expressing the idea of taking them, carrying and/or bringing somewhere as attached to the person $(17 \mathrm{c}-\mathrm{d})$.
a. Tomek poszedł do parku z psem na smyczy
Tomek went.3SG to park with dog on leash
'Tomek went to the park with the dog on a leash'
b. Rozmawiałem $\mathrm{z}$ moim ojcem talked.1SG with my father
'I talked with my father'
c. Poszedł z siekierą do lasu went.3SG with axe to forest
'He went with the axe to the forest'
d. Podróżuje $\mathrm{z}$ dużą walizką came.3SG with big luggage 'He came with big luggage'

The preposition $z$ can also express manner (Wielki słownik języka polskiego PAN 2016; Karłowicz et al. 1927: 5):
a. Czekam z niecierpliwością na list wait.1SG with impatience for letter 'I am impatiently waiting for the letter'
b. Pracuje z niesamowitą gorliwością work.3SG with incredible zeal 'He is working with incredible zeal'

The instrument is normally not expressed by means of $z$, being rather communicated through the use of a noun in the instrumental case (e.g. Zabit go siekiera 'He killed him [with a] an axe'). However, in a few instances, viewed as archaic and/or pleonastic, $z$ can be optionally employed (Karłowicz et. al. 1927: 5): ${ }^{3}$
(19) Handluje z solą trade.3SG with salt
'He sells salt' (cf. Karłowicz et. al. 1927: 5)

\footnotetext{
${ }^{3}$ In modern Polish, $z$ is typically omitted in such cases.
} 
Frequently, the lexeme $z$ has a possessive value if it is used with inanimate nouns and body parts (Wielki słownik języka polskiego PAN 2016):

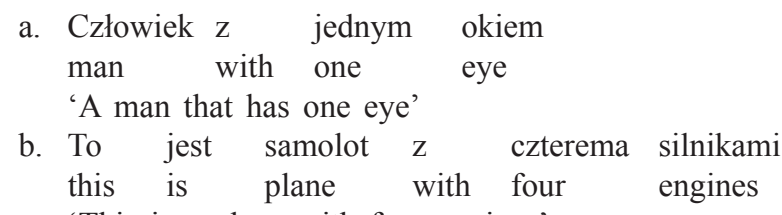
'This is a plane with four engines'

Lastly, the lexeme $z$ may have a temporal sense 'simultaneously to, as soon as' equivalent to jednocześnie $z$ or $z$ nastaniem, for example $z$ mrokiem 'at dusk', $z$ świtem 'at dawn', z nastaniem lata 'as soon as / when summer came/comes' (Wielki słownik języka polskiego PAN 2016; Karłowicz et al. 1927: 5). ${ }^{4}$

\section{Discussion}

The evidence demonstrates that the categorial status of the items $i$ and $z$ when used to coordinate (i.e. when employed as coordinators) is different, the former being significantly closer to the prototype of coordinate-hood than the latter.

The coordinator $i$ exhibits most of the features postulated for the prototype of coordinate-hood. Various conditions are respected: the general semantic criterion ( $F$ 1), the criteria of semantic (F 2), pragmatic (F 3) and syntactic symmetry (F 4), the phonological criterion (F 7), the criterion of optional spatial and temporal simultaneity (F 8), the criterion of the use of independent (emphatic) pronouns (F 9), ${ }^{5}$ the criterion of compatibility with all lexical classes and the ability to link clauses (F 11), the criterion of multiple conjuncts and/or coordinands (F 14), the criterion of a possible omission of non-final conjuncts ( F 15), and the criterion of a bi-syndetic structure (F 16). Certain other conditions are usually respected although in limited exceptional cases, they may be violated. This applies to the following criteria: the morphological criterion of grammatical case (F5), the criterion of morpho-syntactic symmetry related to lexical and syntactic classes (F6), and the criterion of backward anaphora (F 13). The behavior of $i$ with respect to the criterion of extraction (F 12) is more complex. However, the coordinating construction built around $i$ seems, overall, to comply with it, as the majority of extractions are ungrammatical. The interpretation of the data related to agreement (F 10) is also complicated. Even though the plural agreement is possible, the singular form is also acceptable and obligatory in certain instances. In the structure that is crosslinguistically the most typical of agreement (i.e. [A and B verb] where A and B are subjects), the plural form is compulsory, except for some abstract inanimate nouns. Lastly, one criterion (F 17) is inconclusive given that the coordinator and the coordinand that follows may precede verb or be located after the verb in the adjunct position.

\footnotetext{
${ }^{4}$ There is also another preposition $z$ that governs the genitive case. This lexeme is etymologically unrelated to $z$ as discussed in this article (Brückner 1985: 641-642; Karłowicz et al. 1927: 1-6).

${ }_{5}^{5}$ This criterion is only applicable to the non-first coordinand.
} 
When used in a coordinating function, the lexeme $z$ exhibits fewer features associated with the prototype of coordinate-hood. The general sematic criterion (F 1) can be fulfilled and the order of the coordinands reversed (F 4). However, in certain cases, such permutation is impossible or it yields pragmatically marked sentences. As for extraction (F 12), the coordinator $z$ behaves in a manner resembling the lexeme $i$. That is, most types of extractions are impossible, although some are acceptable. Additionally, several criteria of coordinate-hood are met although they may also be (and commonly are) violated - thus the item $z$ exhibiting twofold nature. This holds true for the criterion of symmetrical saliency (F 2), the criterion of equal topicality status (F 3), the criterion of multiple coordinands (F 14), and the criterion of plural agreement, where both singular and plural forms may be employed (F 10). One should note that in the context that most commonly triggers plural agreement crosslinguistically, i.e. [A and B verb], both singular and plural form may be used (cf. the behavior of the lexeme $i$ ). As for the morpho-syntactic symmetry (F 6), the coordinands need not appear in the same syntactic class although they may do so. For instance, while the first coordinand is subject, the second coordinand may be employed as an adjunct. The coordinands tend to belong to the same lexical class. (This, however, stems from the fact that only two lexical classes are normally used in the $z$ coordinating constructions: nouns and pronouns). Various features postulated for the prototype are often violated. The coordinands are usually not marked by the same case since the second coordinand must be inflected in the instrumental (F 5); the coordinator $z$ usually (albeit not always) implies temporal and spatial simultaneity (F 8); only NPs (with their qualifying adjectives) and pronouns can be linked by means of $z$ (F 11); z cannot be omitted (F 15), and cannot be used bi-syndetically (F 16). Lastly, four criteria cannot be tested. These criteria concern the use of independent or dependent pronouns (F 7), the presence of backwards anaphora (F 13), a sub-type of criterion (F 6) related to lexical classes, and word order in SVO structures (F 17).

The two coordinators differ in several other properties. With the lexeme $i$, a possessive anaphoric pronoun must be employed while $z$ necessitates the use of its reflexive counterpart. Although the elements employed in the $i$ and $z$ coordinating constructions are arranged into the typological pattern [A] [co B], the latter exhibits a greater degree of structural asymmetry having a clear prepositional structure. The case of the coordinands introduced by $i$ is not projected by the coordinator but rather derives from the verb or the syntax of the clause. In contrast, $z$ governs the instrumental case. That is, the noun introduced by $z$ must be inflected in instrumental irrespective of its positon and function in the clause. The coordinator $i$ is not sensitive to any word class, nor is it conditioned by the semantic traits of coordinands, with some exceptions related to the number agreement of the verb. In contrast, the coordinator $z$ is sensitive to the parameter of lexical class, being only used with word classes inflected for case (nouns, qualitative adjectives, pronouns). It is also highly sensitive to the syntactic class of coordinands. Being able to link clauses, $i$ can mark the sameness of the subjects or to introduce two different subjects. It can also communicate the nuance of sequentiality. As $z$ cannot link clauses, its relation to the sameness/distinctiveness of the subjects or the idea of sequentiality cannot be analyzed. 
The lexemes $i$ and $z$ differ not only in the degree of canonicity of their coordinating uses, and in other properties exhibited when expressing the idea of coordination. The two forms are additionally compatible with two distinct sets of senses or functions other than coordination, thus yielding different maps of polyfunctionality.

The use of the lexeme $i$ as a verbal and nominal coordinator constitutes the prototypical function of this form. Indeed, $i$ is regularly associated with the idea of coordination by native speakers. However, $i$ also conveys other senses, such as the values of 'also' and 'even', the value of a discourse particle 'well, then', the value of a quantifier 'both', and (although sporadically) a contrastive-adversative sense 'but'. ${ }^{6}$ It can also be used as a semantically-void entity. A major part of the polyfunctionality of the lexeme $i$ (verbal coordination, nominal coordination, 'also' and 'even') can be structured by means of the template proposed by Haspelmath (2004). However, this map fails to make room for three other senses exhibited by $i$ : the contrastive-adversative sense, the discourse particle 'well, then', and the value 'both'. Nor can the use of $i$ as a semantically-empty item be included in that map. As a result, the position of these senses in the map is more or less provisional - their conceptual and diachronic relation to the other senses postulated by Haspelmath should be regarded as tentative. The contrastive-adversative sense likely derives from the value of coordination, as the link between conjunctive coordinators (and) and the contrastive-adversative nuance (but) is well-attested crosslinguistically (see Malchukov 2004). ${ }^{7}$ Since in Polish this value appears when $i$ heads a verbal clause (or a sentence, including elliptic clauses), it has probably emerged from the verbal type of coordination. The function of $i$ as a discourse particle can arguably be derived from the meaning 'also' given that, in Polish, te $\dot{z}$ - the most common word for 'also' - is similarly used as a discourse particle (e.g. Że też ci się chce?! 'How can you want it'). However, it is not impossible that this function of $i$ has been stimulated by its use as a verbal and clausal coordinator. The quantifier function 'both' may constitute an extension from the use of $i$ as an adverb 'also' and/or a nominal-verbal coordinator. This linkage is, however, tentative as more diachronic and typological data are necessary. ${ }^{8}$ Lastly, the position of the semantically empty usage in the map cannot be determined at this stage of research. As a result, the entire polyfunctionality of $i$ can be represented by the following - to a degree tentative - map:

${ }^{6}$ It should be recalled that the use of $i$ in contrastive-adversative functions is highly limited. The lexeme $i$ is only used in one sense that belongs to this "cloud" of senses. Inversely, it is usually incompatible with most contrastive-adversative nuances (Andrason 2017; regarding such sub-senses consult Malchukov 2004). Therefore, even though recognized in the map (see Figure 1 below), the contrastive-adversative use of $i$ is not quantitatively equivalent to the other functions of this lexeme. This also implies that the adversative $i$ should not be equaled with exemplary contrastive-adversative lexemes from a crosslinguistic perspective. It rather corresponds to one of their uses.

${ }^{7}$ Malchukov (2004) makes a distinction between the contrastive and the adversative sense. The contrastive sense is a linking stage towards the adversative (proper) sense.

${ }^{8}$ The derivation of the sense 'both' from 'also' or 'N/V-coordinator' - rather than vice-versa - is plausible given the most likely diachronic origin of $i$. As will be explained below, there is no evidence suggesting that $i$ has emerged from the input lexeme that meant 'both', 'two' or 'all'. 


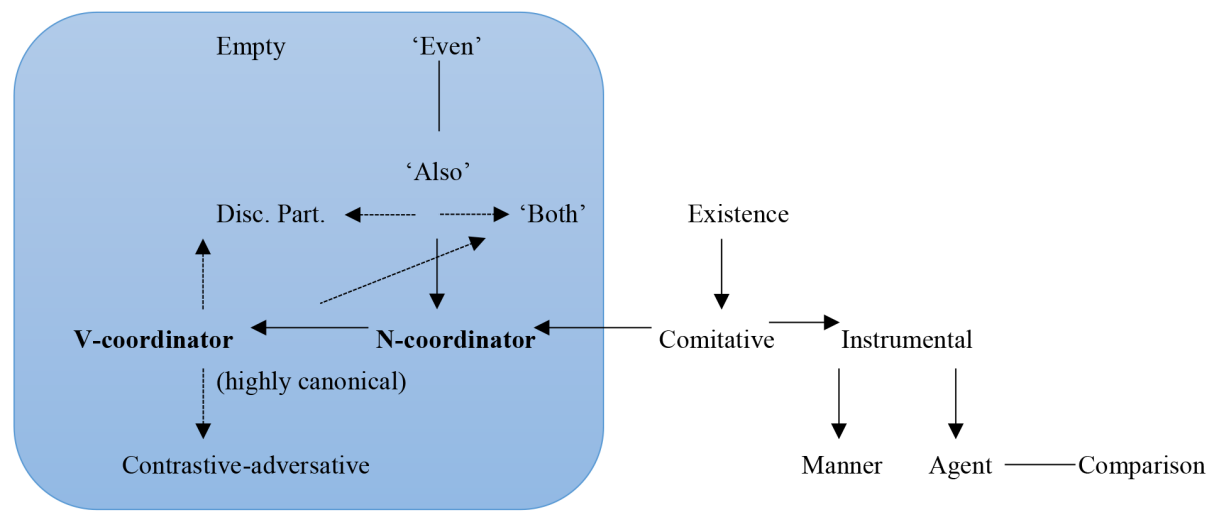

Figure 1. The map of the lexeme $i^{y}$

The map of the lexeme $z$ is less problematic as most functions of this word can be matched with the categories found in Haspelmath's (2004) map. Apart from its use as a less canonical nominal coordinator (which also includes pronouns and, to a degree, adjectives), $z$ conveys a comitative function and the idea of manner and possession. Only extremely infrequently (if ever in normal speech) is it used to express instrument. Additionally, it can convey a temporal sense of simultaneity or immediacy ('simultaneously to, as soon as'). Among all these functions, the comitative and possessive uses are the most prototypical, $z$ being the most common expression of these two ideas in Polish. Two senses that are not included in Haspelmath's template are likely related to the comitative value constituting its meaning extensions (compare the crosslinguistically common use of comitative lexemes to express possession and temporal simultaneity). Consequently, the entire polyfunctionality of $z$ can be mapped in the following manner:

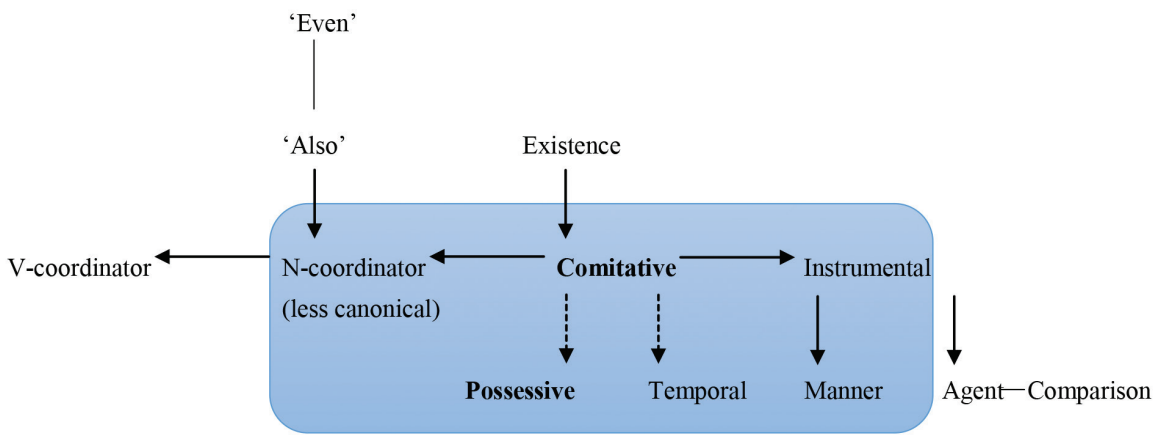

Figure 2. The map of the lexeme $z$

${ }^{9}$ The dashed arrows stand for conceptual and diachronic relations that are not included in the template designed by Haspelmath (2004). Some of them can only be viewed as tentative. The senses in bold type indicate the most prototypical values associated with the lexeme. 
The evidence indicates that the lexemes $i$ and $z$ "specialize" in two different sections of the map. However, they also overlap in one sense, i.e. in the use as a nominal coordinator. Nevertheless, the contribution of this function to the two forms is distinct: the nominal coordination constitutes the prototypicality center of the $i$ form (together with the verbal coordination), while the prototypicality of $z$ is associated with comitative. Furthermore, as explained above, $i$ is a significantly more canonical $\mathrm{N}$-coordinator than $z$.

The maps of $i$ and $z$ not only schematize and explain the synchronic dissimilarity of these two forms. They also suggest distinct diachronic and conceptual origins of the two lexemes, distinct grammaticalization paths along which they have been developing, and a distinct degree of advancement on them. This means that the contrast between $i$ and $z$ is dynamic, not only static. Even though the two forms can be mapped by means of a comparable template, which they partially share, they constitute two different dynamic phenomena, being governed by different diachronic and cognitive processes. To be exact, the coordinator $i$ seems to have derived from the meaning 'also' (or a related nuance) and not from a comitative/existential sense. The situation of the coordinator $z$ is inverse as it likely descends from a comitative value. Accordingly, the meaning extensions available to the two evolving objects are distinct. That is, since certain conceptual and diachronic derivations are unidirectional, some meanings cannot be "reached" by $i$ (e.g. comitative and all its extensions), while others remain beyond the scope of $z$ ('also' and 'even'). As far as the grammaticalization process leading towards coordinators is concerned, $i$ has travelled it more extensively than $z$.

Since the scope of this paper is synchronic (albeit dynamic), the diachrony of the two forms will only be discussed briefly. The Polish lexeme $i$ comes from Proto-Slavic $* i$ as documented by Old Church Slavonic $i$ 'and, also', which reflects *h, ei of Proto-Indo-European (Derksen 2008: 207). It is probably related to Greek ei 'if, whether' and 'so' (Brückner 1985: 189; Pokorny 2007: 852; Derksen 2008: 207). The exact etymology of the Greek item and its Proto-Indo-European source is uncertain (Beekes \& van Beek 2010: 379). This origin may be interjective, locative or demonstrative. However, it does not seem to be related to a comitative value (for details, see Schwyzer 1950: 557, 683; Pokorny 2007: 851-852; Beekes \& van Beek 2010: 379). The lexeme $z$ (governing the instrumental) comes from an older $s$ that reflects Proto-Slavic $*_{s}(n)$ (compare the Old Church Slavonic preposition $s z$ 'with' and the prefix $s b^{-}$'together') and Proto-Indo-European $*_{s m}$ (Bruckner 1985: 641-642; Pokorny 2007: 2607; Derksen 2008: 478). It is related to the prefix $s q$ - 'together' (compare sasiad 'neighbor') from Proto-Slavic * $s Q$ - and Balto-Slavic and Proto-Indo-European *som (Bruckner 1985: 641-642; Pokorny 2007: 2607; Derksen 2008: 462, 478). Given the meaning of the cognates of $z$ attested in various languages, the origin of this lexeme seems to be comitative. Accordingly, the diachronic evidence is consistent with the mapping proposed in this section.

The evidence and the geometry of $i$ and $z$ may also have some implications for the mapping of coordinating lexemes and for the general theory of semantic maps of coordinators. First, certain new senses can be included in the typological map of coordinative forms: possession and temporal simultaneity (which most likely derive from comitative); a contrastive-adversative sense (which has likely emerged from the sense of coordination); the value of a discourse particle 'well, then' (which is probably related to the sense of 
'also'); and the quantifier 'both' (which may be connected to the adverb 'also' and/or 'N/V-coordinator'). The inclusion and the position of the possessive, temporal and contrastive-adversative senses seem to be especially compelling given their crosslinguistic pervasiveness. Second, the fact that $z$ has almost lost its instrumental value (in fact, in normal colloquial speech it is virtually never used in this function) suggests that islands in semantic maps are possible, and that synchronically the connectivity principle is not necessary (contra Haspelmath 2004). ${ }^{10}$

Lastly, the results of this paper indicate that complexity (Massip-Bonet 2013; Mufwene 2013; Bastardas-Boada 2013; Munné 2013) ${ }^{11}$ and fuzziness or gradience (Aarts 2007; Traugott \& Trousdale 2010) are crucial concepts in grammar, both in the analysis of (idealized) grammatical categories and (actual) grammatical forms. As for complexity, the following should be noted. The concept of prototype is complex. In this study, it is related to seventeen features. Some of such features constitute, themselves, complex sets of more atomic properties. An actual grammatical form and its relation to other (similar) forms are also complex matters. With respect to coordination, forms differ by performing differently on the tests that show their canonicity. They can diverge by exhibiting other properties that, even though not directly related to the status of canonicity of coordinate-hood, importantly condition their behaviors as coordinators. Furthermore, the total meaning of a form is complex. Forms comprise distinct sets of senses that can also be structured differently. All of this implies that the categorial status of an item (its canonicity or proximity to the prototype) as well as the systemic contrast between two (or more) forms can only be analyzed and expressed in fuzzy (gradual and scalar) terms. Categories are fuzzy as they transmute from one to another with no clear borderlines. Forms are fuzzy as they fail to fit any rigid categorial taxon - they are rather compatible with different taxa and to different degrees. Even some tests are scalar, as the compliance with a criterion is multivalent (i.e. greater or lesser), rather than bivalent (i.e. total or none).

\section{Conclusion}

By viewing the grammatical category of coordinators as a radial network organized around an idealized prototype that is instantiated in concrete languages by more or less canonical representatives, and by analyzing the polyfunctionality of coordinating forms as a map structured along a grammaticalization path, the present study demonstrated the

${ }^{10}$ This harmonizes with my previous observations whereby extensive polysemous (or polyfunctional) networks may contain "islands", which usually constitute old (or the oldest) senses. This can be illustrated by the categorial split between Preterite-Present verbs and the Preterite in Germanic (Andrason \& Locatell 2016), and the split polysemy of the qatal form in Biblical Hebrew. In both cases, the resultative proper value is (virtually) lost (the diachronic center of the map) such that certain more advanced senses are not connected to the other senses (Andrason 2016). Of course, the connectivity principle is obligatory from a conceptual and diachronic (i.e. dynamic) perspective.

${ }^{11}$ The term 'complexity' is understood in the sense of complex-system theory (Auyang 1998; Hooker 2011). 
following: the taxonomical status of the coordinators $i$ and $z$ is different. The former is a (highly) canonical instantiation of the category (it approximates the prototype of coordinate-hood to a high degree) while the latter is significantly less canonical (it is more remote from the prototype). The two lexemes also differ with respect to their maps of polyfunctionality. That is to say, they specialize in different portions of the map, which reflects their distinct diachronic and hence conceptual origin. In the fragment in which they overlap (i.e. nominal coordinator), their canonicity is different, as is the contribution of this value to the total meaning of the two forms (and thus their perception by speakers). As for $i$, its use as a nominal coordinator is taxonomically canonical, being also prototypical in this form's semantic potential. In contrast, as far as $z$ is concerned, the same sense is non-canonical and non-prototypical - the nucleus of prototypicality of this lexeme being located in the comitative and possessive senses. Overall, the study corroborates the understanding of grammar and its elements as complex and fuzzy.

\section{References}

Aarst, Bas. 2007. Syntactic gradience. Oxford: Oxford University Press.

Andrason, Alexander. 2016. The complexity of verbal semantics - an intricate relationship between QATAL and WAYYIQTOL. Journal of Hebrew Scriptures 16(4). 1-96.

Andrason, Alexander. 2017. The coordinator $i$ and $z$ : A cognitive-typological approach (Part 1). Lingua Posnaniensis 28(1). 7-24.

Andrason, Alexander \& Locatell, Christian. 2016. The perfect wave. Biblical and Ancient Greek Linguistics 5.

Auyang, Sunny. 1998. Foundations of complex-system theories. Cambridge: Cambridge University Press.

Bastardas-Boada, Albert. 2013. General linguistics and communication sciences: Sociocomplexity as an integrative perspective. In Massip-Bonet, Àngeles \& Bastardas-Boada, Albert (eds.), Complexity perspectives on language, communication and society, 151-173. Heidelberg: Springer.

Beekes, Robert \& van Beek, Lucien. 2010. Etymological dictionary of Greek. Leiden: Brill.

Bhat, D. N. S. 2004. Conjunction and personal pronouns. In Haspelmath, Martin (ed.), Coordinating constructions, 89-108. Amsterdam: John Benjamins.

Brückner, Aleksander. 1985. Słownik etymologiczny języka polskiego. Warszawa: Wiedza Powszechna.

Buttler, Danuta \& Kurkowska, Halina \& Satkiewicz, Halina. 1971. Kultura języka polskiego. Zagadnienia poprawności językowej. Warszawa: PWN.

Derksen, Rick. 2008. Etymological dictionary of the Slavic inherited lexicon. Leiden: Brill.

Hamawand, Zeki. 2016. Semantics. A cognitive account of linguistic meaning. Sheffield: Equinox.

Haspelmath, Martin. 2004. Coordinating constructions: An overview. In Haspelmath, Martin (ed.), Coordinating constructions, 1-40. Amsterdam: John Benjamins.

Hooker, Cliff. 2011. Introduction to philosophy of complex systems A. In Hooker, Cliff (ed.), Philosophy of complex system, 3-90. Amsterdam: Elsevier.

Janda, Laura. 2015. Cognitive linguistics in the Year 2015. Cognitive Semantics 1. 131-154.

Kallas, Krystyna. 1993. Składnia wspótczesnych polskich konstrukcji wspótrzędnych. Toruń: Wydawnictwo Uniwersytetu Mikołaja Kopernika.

Karłowicz, Jan \& Kryński, Adam \& Niedźwiedzki, Władysław. 1927. Słownik języka polskiego. Tom VIII. Warszawa: Wydawnictwo Kasy im. Mianowskiego Instytutu Popierania Nauki.

Malchukov, Andrej. 2004. Towards \& Semantic Typology of Adversative and Contrast Marking. Journal of Semantics 21. 177-198.

Massip-Bonet, Àngeles. 2013. Languages as a complex adaptive system: Towards an integrative linguistics. In Massip-Bonet, Àngeles \& Bastardas-Boada, Albert (eds.), Complexity perspectives on language, communication and society, 35-60. Heidelberg: Springer. 
Mufwene, Salikoko. 2013. The emergence of complexity in language: An evolutionary perspective. In Massip-Bonet, Àngeles \& Bastardas-Boada, Albert (eds.), Complexity perspectives on language, communication and society, 197-218. Heidelberg: Springer.

Munné, Frederic. 2013. The Fuzzy Complexity of Language. In Massip-Bonet, Àngeles \& Bastardas-Boada, Albert (eds.), Complexity perspectives on language, communication and society, 175-196. Heidelberg: Springer.

Partee, Barbara \& Rooth, Mats. 1983. Generalized conjunction and type ambiguity. In Bäuerle, Rainer \& Schwarze, Christoph \& von Stechow, Armin (eds.), Meaning, use and interpretation of language, 361-383. Berlin: De Gruyter.

Patejuk, Agnieszka \& Przepiórkowski, Adam. 2012. Lexico-semantic coordination in Polish. In Butt, Miran \& King, Tracy Holloway (eds.), Proceedings of the LFG12 Conference, 461-478. Stanford: CSLI Publications.

Pokorny, Julius. 2007. Proto-Indo-European etymological dictionary. A revised edition of Julius Pokorny's Indogermanisches etymologisches Wörterbuch. Moskva: DNGHU, Indo-European Language Association.

Prażmowska, Anna. 2013. Polish Coordination as Adjunction. In Surányi, Balázs (ed.), Proceedings of the Second Central European Conference in Linguistics for Postgraduate Students, 203-218. Budapest: Pázmány Péter Catholic University.

Przepiórkowski, Adam \& Patejuk, Agnieszka. 2014. Koordynacja leksykalno-semantyczna w systemie współczesnej polszczyzny (na materiale Narodowego Korpusu Języka Polskiego). Język Polski 94(2). 104-115.

Schwyzer, Eduard. 1950. Griechische Grammatik. Bd. 2: Syntax und syntaktische Stilistik, vervollständigt und herausgegeben von Albert Debrunner. München: C. H. Beck.

Traugott, Elisabeth Closs \& Trousdale, Graeme. 2010. Gradience, gradualness and grammaticalization: How do they intersect? In Traugott, Elisabeth Closs \& Trousdale, Graeme (eds.), Gradience, gradualness and grammaticalization, 19-44. Amsterdam: John Benjamins.

Wielki słownik języka polskiego PAN [Polish Academy of Sciences Great Dictionary of Polish]. Warszawa: Polish Academy of Science. www.wsjp.pl [accessed on 15.07.2016].

Willim, Ewa. 2012. Concord in Polish coordinate NPs as agree. In Ziková, Markéta \& Docekal, Mojmír (eds.), Slavic Languages in Formal Grammar. Proceedings of FDSL 8.5, Brno 2010, 233-253. Frankfurt am Main: Peter Lang.

Yuasa, Etsuyo \& Sadock, Jerry. 2002. Pseudo-subordination: a mismatch between syntax and semantics. Journal of Linguistics 38(1). 87-111. 